\title{
A study of the role of Islamic spirituality in happiness of Muslim citizens
}

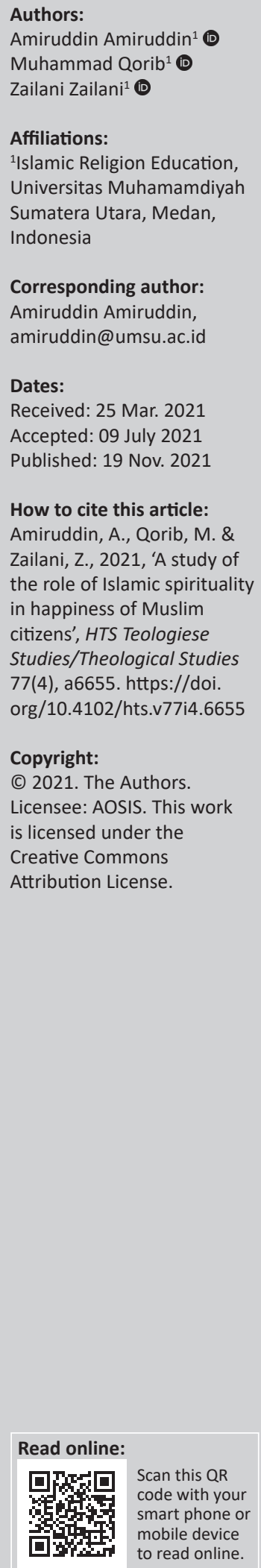

Recreation and joy are considered as the basic needs of humans. When the human body and soul get tired, they yearn refreshment through various means. Since the primary goal of Islam is true perfection of humans and achieving higher meaning and purpose in life, the happiness emphasised in this school of thought must be such that it does not conflict with the goal of creation and the ultimate perfection of humans. Therefore, this study aimed to determine the role of Islamic spirituality in the happiness of 5000 citizens of Volga Federal District in Russia. The statistical population of the study was selected by simple random sampling method and the collected data was analysed by Structural Equation Modelling method in the LISREL software. The results indicated the positive role of Islamic spirituality in determining the happiness among citizens (Path Coefficient: 0.821; $T$ value: 24.83). Hence, human beings should look for happiness in life through circumstances that can control the critical factors and create the ground for happiness and self-esteem, which is nothing but religion, religious actions and behaviours, and spirituality. Therefore, in order to experience greater happiness and to be immune to anxiety and depression, one should follow the religion and Islamic spirituality, and achieve a greater sense of happiness by remembering God and performing religious actions and behaviours.

Contribution: This article contributes to the relationship between happiness, human body and religious beliefs.

Keywords: Islam; religion; spirituality; Islamic spirituality; happiness; Russia.

\section{Introduction}

As for the relationship between happiness and spirituality, everyone may have a specific understanding of the concept of 'happiness' and accordingly strive to achieve and provide the preconditions for happiness. The definition of happiness, consistent with the religious approach, is that one feels satisfied and happy in one's life and enjoys mental health. According to Islam and the Qur'an, the believer is the happiest person. As per this definition, the relevant question is what can do to be able to feel satisfied in life and maintain our happiness and mental health. The main factors that deprive a person of happiness in life and cause anxiety, depression and various mental disorders include falling into the trap of instincts, feelings of emptiness, meaninglessness and helplessness in the face of life events and crises. Therefore, we must seek our own happiness in life in matters that can control these critical factors. Many psychologists believe that the most important factor that can control the critical factors of life and create happiness and a sense of self-worth in human beings is nothing but religion and religious practices and behaviour.

Both the individual orders and the social orders of Islam are based on satisfaction, joy, vitality and mobility. Careful observance of these commandments, apart from the element of satisfaction that guarantees lasting happiness, indicates joyful and uplifting behaviours and actions. Islamic holidays, such as Eid al-Fitr, Eid al-Adha, etc., induce behaviours and thoughts of living happily.

Based on the Islamic social commands to serve society and people, apart from the philosophy of servitude and obedience, God causes the spread of friendships, affections, and empathies among human beings. When people serve each other, an atmosphere of love, satisfaction and happiness prevails in the society and people enjoy every moment of their life in that society. According to Islam and the Qur'an, the believer is the happiest human being, because he does not boast or complain about the hardships of the times. The believer does not consider the world as a place to 
stay, but considers it as a temporary stop. The believer endures hardships and spends the moments feeling satisfied and happy in the physical life waiting to join Allah eternally in the spiritual life. Because of this satisfaction and joy of the believers, God Almighty lovingly invites them to their own paradise, and arranges moments of joy for them, in accordance with a verse of 'O Tranquil soul, return to your Lord well pleased and pleasing [Him]!, Join My worshipers, and enter My Paradise!' (The Holy Qur'an, Surah Al-Fajr, Ayat 27-30). Given the importance of the issue, this study aims to examine the role Islamic spirituality plays in the happiness of Russian Muslim citizens in 2020.

\section{Islamic spirituality}

Spirituality is one of the emerging words in today's society. It has a broad meaning in the Western culture and involves any semantics. But what we are referring to here is spirituality from the Islamic point of view. Spirituality per se is not mentioned in the Qur'an and the hadiths. Spirituality in its literal sense means the inner world and truth the soul of the material world and appearances. Based on this, the closest word that we can say defines spirituality in Qur'an is 'good life and divine light'. According to Ayat 97 of Surah An-Nahl, faith and righteous deeds are the main cause of such life, which is called the good life:

Whoever does righteousness, whether male or female, while he is a believer - We will surely cause him to live a good life, and We will surely give them their reward [in the Hereafter] according to the best of what they used to do.

Accordingly, spirituality is the result of the process of knowledge, faith and righteousness within the framework of Islamic law. Thus, if good life and the light of the heart are not obtained, spirituality is not obtained. Spirituality has no meaning without knowledge of the truths of the realm of the material world, as well as faith in God and His attributes and actions. A large part of spirituality is formed in the light of good deeds, and righteousness is necessary for correct faith and consistency of spirituality, and violating these action beads to destruction of spirituality. Islamic teachings offer the deepest and most comprehensive divine knowledge in various chapters. In addition, they explain in detail the good deeds which can establish great spirituality. Spirituality does not stop at a fixed point. It has strengths as well as weaknesses and difficulties. Spirituality not only varies from people to people, but may decrease and increase in one person also. As the Qur'an says, 'We have created man with the finest stature; then reduced him to the dregs on the bottom' (The Holy, Qur'an, Surah At-Tin, Ayat 4-5). According to the Holy Qur'an, faith is a matter of the heart, which is loved by the hearts of believers and is adorned in their hearts by God:

And know that among you is Allah's Messenger: where he, in many matters, to follow your (wishes), ye would certainly fall into misfortune: But Allah has endeared the Faith to you, and has made it beautiful in your hearts, and He has made hateful to you Unbelief, wickedness, and rebellion: such indeed are those who walk in righteousness. (The Holy, Qur'an, Surah Al-Hujurat, Ayat 7)
Therefore, faith is a matter of the heart, of which verbal and practical confession is a requirement (Tabatabai 1985). Hence, Prophet Muhammad said, 'faith is a matter of knowing with the heart, speaking with the tongue and acting with the limbs and joints'. Faith is one of the inner tendencies of man, and is based on belief and thought. According to the Qur'an and Sunnah, religious faith has many achievements, including spirituality, such that strengthening faith will strengthen spirituality (Mohammadi Rey Shahri 2000).

\section{Living happily in accordance with Islamic teachings}

According to Islamic teachings, the principles for living happily include:

(1) Remembrance of God: According to Islam, there is no pleasure in living without remembrance of God. God says in the Holy Quran: 'and whoever disregards my remembrance, his shall be a wretched life' (The Holy, Qur'an, Surah Taha, Ayat 124). Whoever turns away from God will have a hard and difficult life. When we forget God, our life becomes difficult, and our steadfast faith in God brings happiness to our lives. This joy in life is the result of the calmness of heart and the peace of mind that comes from remembering God. God says: 'now surely by remembrance of Allah are the hearts set at rest' (Surah Ar-Rad, Ayat 28). The psychological explanation for this is that the remembrance of God steers a person away from desires and impulses that cause stress and mental strain. It also causes one to pay attention to strengthening the relationship with God and approaching Him, instead of simply focusing on worldly pleasures. Problems do not prevent the believer from achieving the main goal, and because the believer is on the path of spiritual growth and development (Muhammad ibn Ya'qub Kulayni 1983), he will enjoy life. Therefore, in large part happiness can be achieved in by remembering God and more so in every situation (KhalajiMovahed 2000).

(2) Trust in God: Trust in God is the cornerstone of a happy and blissful life. A man who trusts in God, stands in the face of adversity with all his might, and never feels defeated or worried. If we trust in God, in our actions and plans, we will not only achieve significant success, but we will also find the strength and resilience to successfully navigate through all the hardships and difficulties that we counter in life. Trust is the key to divine grace. A person who relies on God is under the infinite care and grace of God at all times (IbnBabawiyyah 1983).

(3) Adherence to values: Adherence to fixed and defined values and beliefs contributes to success in human life and it also sustains happiness. A non-believer feels alienated from life leaning towards emptiness, which is one of the main causes of depression and unhappiness. A non-believer is rootless in existence and creation (TamimiAmadi 1987), and will not feel real happiness. Just as it is not possible to succeed in life without a plan, similarly without faith and transcendent values we cannot enjoy life and feel happy. 
(4) Satisfaction with life: Satisfaction is imperative for living happily. There are people who have immense success, wealth and opportunities, but they always complain about life and do not feel happy. While there are people who are among the poorest and have many problems in life, but they live happily, because they are satisfied and contented with their life. Therefore, human happiness is not dependent on having or not having, but it depends on satisfaction or dissatisfaction. Satisfaction guarantees happiness. Dissatisfaction with life can be attributed to self-made expectations. Everyone has expectations about the course of their life and destiny, but when things do not go according to human desires, they feel dissatisfied (Seligman 2004).

(5) Hope for the future: When we create beautiful images of the future instead of the cluttered, chaotic and negative images, we will feel happy. Psychological findings and life experiences have proved that the future is made by human mental images. That is, whatever one expects and imagines of the future, the same expectation and image will be realised. Hope is the most beautiful feature of a dream. If we want to enjoy life, we must live with hope. The hope (a positive image of the future) keeps man alive. Therefore, we must create a beautiful image of the future and we must always be hopeful and visualize the future, as we like. We need to believe that we are becoming more successful, happier and happier dayby-day (James 2011).

(6) Purposefulness: Purposefulness not only guarantees human success, but also causes human happiness. An aimless person is like a wanderer in a burning desert, and his life will be devoid of calmness and happiness. Some people equate purposefulness with achieving big and great aspirations, but most of them do not succeed in life. Wishes must be clear, definite and defined. A great dream is excellent, but first and foremost, we must provide the necessary energy and power to achieve our dream, and secondly, that desire must be clear to us, in which case we will surely succeed. A firm decision to achieve a beautiful and sacred goal should not destroy human happiness, because man has no duty but to act. We must do our best to achieve the best of the goals. If we achieve those goals, we will feel happy and if not, we will be unhappy. Therefore, it is necessary for human beings to have clear and transparent goals in life.

(7) Believing in happiness: The biggest problem of unhappy, depressed and dissatisfied people is that they do not believe in themselves or their happiness, and in living happily. A person who believes in himself can live happily. We must therefore believe that we can be happy and we will be happy. Because we are created to be happy, we must believe that life is beautiful and enjoyable. We must believe that destiny is a function of our beautiful thoughts; we must believe that God loves us and is the most merciful (Shahidi 2019).

(8) Avoiding unnecessary and wrong rituals: Being comfortable in life leads to happiness. The more the people torment themselves with unnecessary customs and rituals, the more they turn away from happiness. Many people make simple, beautiful and comfortable life unnecessarily difficult and complicated. Traditions and customs typically guide us on the path to happiness and divinity. But superfluous and wrong rituals lead to disorder, complications and unhappiness. As life becomes more complicated and formal, the mental tensions and pressures intensify. Therefore, if we want to lead a happy life, we must put aside unnecessary formalities and live comfortably and intimately.

(9) Honesty: Honesty is like the clear water that irrigates the lawn of happy life, and blossoms the flowers of happiness and joy. Honest people experience happy moments and enjoy every moment of life. Choosing honesty means choosing happiness. Honesty is one of the most beautiful messages of Islam. An honest person will be saved from all troubles and problems. Hypocrisy is not worthy of man's divine status, and it will certainly disgrace man. If man behaves honestly even in the most adverse situation, it will end in his favour; an honest human being is trustworthy (Majlisi 1983). Therefore, if we practice honesty in all our actions and lives, we will always have a happy life and we will be respected by all human beings.

(10) Positivism: Positive and impartial judgement is one of the best ways to live happily. If man learns to judge positively and avoids negative, pessimistic, and selfish judgements and prejudices, he will not become angry or greedy. Rather, he will feel happy in all situations and will live happily with all human beings (Saliba \& SaneiDarhbidi 1987).

\section{Methodology}

The present study is applied in terms of purpose and descriptive research. In terms of data collection, it is a branch of field studies, and is a descriptive-survey in terms of the relationship between research variables. The statistical population of the present study consisted of 5000 citizens of Volga Federal District, one of the eight federal districts of Russia, who were selected through simple random sampling method. Data were collected using the 20-items questionnaire of Multidimensional Measure of Islamic Spirituality provided by Dasti and Sitwat (2014). Happiness was measured using 29-items Oxford Happiness Questionnaire (Hills \& Argyle 2002). The validity of the questionnaires was confirmed by the professors through the content validity. The reliability of the questionnaire was also calculated by Composite Reliability (CR). The coefficient obtained for the whole questionnaire is equal to 0.884 . If the $C R$ is greater than 0.7 , the reliability of the questionnaire is confirmed. After receiving the questionnaires, 4654 questionnaires were completed properly, the demographic information of which is as follows: participants consisted of 53\% men and $47 \%$ women, $65 \%$ married and 35\% single, $20 \%$ without academic education, $58 \%$ with a bachelor's degree, and $22 \%$ with the educational level of higher than bachelor's degree, 32\% under the age of 30 years, $47 \%$ with age between 30 and 40 years, and 21\% with age over 40 years. 


\section{Results}

Structural Equation Modelling in LISREL software was used to investigate the relationship between Islamic spirituality and happiness. Figure 1 shows the research model; according to the path coefficient and $\mathrm{T}$ Value, the hypothesis has been confirmed or rejected.

Research Hypothesis: Islamic spirituality has a significant and positive relationship with happiness of Muslim citizens in Russia.

\section{Discussion}

The aim of the current study is to determine the role of Islamic spirituality in the happiness of 5000 citizens of Volga Federal District in Russia in 2020. The results indicated the positive role of Islamic spirituality in determining the happiness among citizens (Path Coefficient: 0.821 ; $T$ value: 24.83) (Table 1). Happiness is one of the fundamental emotions of human beings, with a decisive role in ensuring the health of the individual and society. Happiness can improve physical health. Happy people feel more secure, make decisions easily, and have a higher participatory spirit. Happiness is always accompanied by joy, optimism, hope and trust; hence, it can play a facilitating role in the sustainable development of communities. The psychological benefits of happiness are no less than its physical benefits, as happiness causes a person to feel strong and light, and eliminates vague and painful feelings, dull and occasional headaches, feelings of laziness and endless fantasies, worries of selfishness, and so on. Happiness can lead to better ways to continue living. Happiness also has positive effects on social interaction, perception and cognition, and is effective in increasing creativity and longevity. In contrast, low levels of satisfaction and feelings of unhappiness lead to negative attitudes towards society as a whole. Long periods of unfulfilled aspirations and expectations lead to the emergence of pessimistic attitudes that are passed down from generation to generation.

According to Islamic thinkers such as Farabi, Ibn Sina, Ghazali and Razi, and psychologists such as Freud, one of the main reasons for abating happiness and rising depression is the feeling of missing a loved one or an object. According to Islam and Islamic psychologists, a healthy person should not become attached to loved ones as we are all mortal beings and should not feel sad when we lose them. Islam has

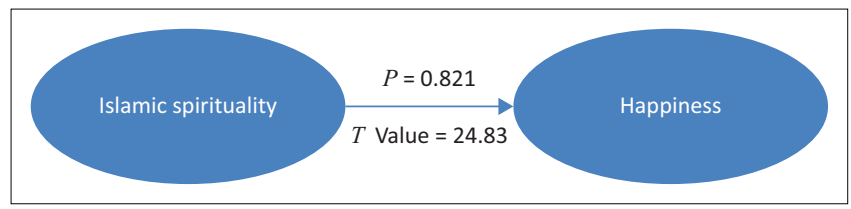

FIGURE 1: Structural equation modelling of research.

TABLE 1: Hypothesis test.

\begin{tabular}{llccc}
\hline No. & Hypothesis & Path coefficient & $\boldsymbol{T}$ value & Result \\
\hline 1 & Islamic Spirituality $\rightarrow$ Happiness & 0.821 & 24.83 & Confirmed \\
\hline
\end{tabular}

introduced various examples of lasting and indestructible joys. These include among other: romantic prayers, prayers with passion, worship with sincerity, helping the helpless and poor, aid the orphans, feeding the hungry, visiting relatives, talking to a close friend, expressing love to wife and children, creating happiness in the hearts of others, and so on. Such actions create and further lasting joy and happiness.

On the one hand, there is a balanced, realistic and scientific approach to religion, which considers the extremism and permissibility of any happiness in human life. On the other is the deviant approach to religion that opposes religion to any happiness that results from a lack of proper knowledge of religious teachings. The message of religion to human beings is that the way to salvation from sorrow is faith in God and His expression that gives peace and happiness to human beings. The Holy Qur'an affirms and directs happiness, which is a natural human need, and provides the necessary guidance for attaining and enjoying happiness. The necessity of happiness in human life has been confirmed with the help of religious texts. A monotonous life and work pressures lead to fatigue and boredom. Hence, numerous narrations have stated that it is necessary to know how to be happy and to study the joyful factors such as the use of pleasures, eloquent and joyful words that can reduce this fatigue and boredom. In the narrations of religious leaders, the method of dividing the times and hours of the day into different sections has been considered, one of which is dedicated to psychological happiness and pleasures. This is a proof of happiness and its necessity for human beings from the point of view of religious leaders.

\section{Conclusion}

The Qur'an and Islamic traditions have taken a very positive view of certain joyful factors such as travel, entertainment, recreation, sports, and meeting friends. The emphasis of religious leaders on teaching sports to children and enumerating the benefits of travel and recreation is a definite reason for their desirability in religion. With the guidance of religious sources, true happiness can be distinguished from false and fleeting joys. Community leaders need to design the community space in such a way as to address the joys that are essential to life. The results obtained from the present study demonstrated that spirituality by focusing on the Islamic approach affects the happiness of people in society. Therefore, strengthening religious spirituality based on Islamic teachings can bring in a prosperous society.

\section{Acknowledgements Competing interests}

The authors declare that they have no financial or personal relationships that may have inappropriately influenced them in writing this article.

\section{Authors' contributions}

The authors contributed equally to the writing of this article. 


\section{Ethical considerations}

This article followed all ethical standards for research without direct contact with human or animal subjects.

\section{Funding information}

This research received no specific grant from any funding agency in the public, commercial or not-for-profit sector.

\section{Data availability}

Data sharing is not applicable to this article as no new data were created or analysed in this study.

\section{Disclaimer}

The views and opinions expressed in this article are those of the authors and do not necessarily reflect the official policy or position of any affiliated agency of the authors.

\section{References}

Dasti, R. \& Sitwat, A., 2014, 'Development of a multidimensional measure of Islamic spirituality (MMS)', Journal of Muslim Mental Health 8(2), 77-94.

Hills, P. \& Argyle, M., 2002, 'The Oxford Happiness Questionnaire: A compact scale for the measurement of psychological well-being', Personality and Individual Differences 33(7), 1071-1082.

IbnBabawiyyah, M.i.A., 1983, al-Alami, Dar al-Kitab Publication, Beirut.

James, W., 2011, The varieties of religious experience, Cambridge University Press, Cambridge.

KhalajiMovahed, A., 2000, Psychotherapy with heavenly word, City of Thought Publication, Tehran.

Majlisi, M.B., 1983, Bihar al-Anwar, Dar Al-Ahya Al-Arabi Heritage, Beirut.

Mohammadi Rey Shahri, M., 2000, The amount of wisdom, Dar al-Hadith Institute, Qom. Muhammad ibnYa'qubKulayni, 1983, al-Kafi, Dar Sa'b Publication, Beirut.

Saliba, J. \& SaneiDarhbidi, M., 1987, Philosophical culture, Hekmat Publication Tehran. Seligman, E.P.M., 2004, Authentic happiness, Atria Books Publication, New York, NY.

Shahidi, S., 2019, Psychology of happiness, 3rd edn., Qatreh Publication, Tehran.

Tabatabai, S.M.H., 1985, Tafsir al-Mizan translation, Cultural Foundation of AllamehTabatabai, Tehran.

TamimiAmadi, A.W.M., 1987, TasnifGharr al-Hakam and Dar al-Kalam, Islamic Propagation Office, Qom. 